\title{
Straddle Option Profitability In Corporate Lawsuits
}

\author{
Erica A. Wind, Colorado College
}

Judith A. Laux, (E-mail: jlaux@coloradocollege.edu), Colorado College

\begin{abstract}
The current study investigates whether abnormal returns may be gained by purchasing a straddle position prior to a verdict or settlement announcement in a lawsuit. The basis for the hypothesis stems from behavioral finance-more specifically, the Overreaction Hypothesis. Using CAPM expected rates of return and comparisons of 31 lawsuit firms' straddle returns, three new straddle trading strategies are devised. Within the sample of lawsuits, abnormal returns are evident for the three strategies. The results and their implications support behavioral finance and the Overreaction Hypothesis and thus refute the Efficient Markets Hypothesis.
\end{abstract}

\section{INTRODUCTION}

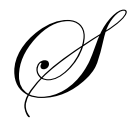

ince its inception in 1973 on the Chicago Board Options Exchange, the standardized options market's popularity has increased exponentially. On the first day of operation the CBOE traded 911 contracts, and by the year 2000, that number had grown to approximately one million contracts per day [CBOE, 2006]. In the past, options trading remained primarily in the realm of brokers and professionals, partially due to the complicated nature of options strategies. However, the Options Industry Council now offers educational courses and publishes free brochures, such as "The Equity Options Strategy Guide," widely available to any investor interested in becoming an active options trader [The Options Industry Council, 2006]. Additionally, the growing number of available discount electronic brokers has fostered competition for clients and decreased the commissions and fees associated with simple transactions, making options spreads more feasible trading strategies for casual investors.

One of the most popular options strategies to emerge is the straddle, which consists of a long call and long put on the same underlying stock. This strategy is designed to profit from a stock's price volatility. Events that cause a severe jump or decline in stock price can lead to a profitable options straddle. One such event that may lead to such a jump or decline is a verdict or settlement announcement where one of the parties involved in the lawsuit is a publicly traded firm.

Between 1960 and 1990, lawsuits increased by 280\%, and between 1971 and 1991 in at least 62\% of lawsuits, at least one party was a firm [Koku et al., 2001, p. 50]. More recently, the monetary damages awarded in cases filed by the Equal Employment Opportunity Commission have increased from $\$ 36.4$ million in 1993 to $\$ 148.7$ million in 2003 [EEOC Litigation Statistics, 2006]. The combination of the increasing number of lawsuits and the increasing number of available options may provide the investor with a new source of profit to add to his or her portfolio, if a relationship between the straddle profit and lawsuits is supported. The current study investigates whether a verdict or settlement announcement in a corporate lawsuit influences the firm's stock price enough to lead to a profitable straddle options' position.

The underlying assumption regarding a verdict announcement is that the announcement introduces new information to the market about the firm's future prospects. If a publicly traded firm is required to pay a large sum in monetary damages or loses the right to sell a key product due to patent infringement, investors' ideas regarding the future profitability of the firm may change quickly and drastically. If investors anticipate a dramatic verdict prior to its actual announcement, their expectations regarding future price volatility may become evident via a 
change in firm valuation shortly after the filing announcement of a lawsuit. If this scenario holds true, it may still be possible to reap a profit by engaging in a straddle early in the litigation process, as the stock's value may increase or decrease substantially in the time leading up to the verdict announcement.

This paper first examines the literature relevant to the present study, including the Efficient Market Hypothesis, behavioral finance theory, and options pricing and profit models. Empirical studies pertinent to these theories bridge the gap between the theoretical and the tangible as they demonstrate how the validity of these economic theories is tested for the capacity to explain real world data and phenomena. Several studies use methods that serve as templates for the current study's methods. The current empirical study regarding the profitability of a straddle options position in relation to a verdict or settlement announcement compares straddle returns to market returns, competitors' returns, and required rates of return. From these analyses, new straddle options trading strategies are then derived.

\section{REVIEW OF LITERATURE}

In 1965 Fama introduced his "random walk" theory, later to be known as the Efficient Markets Hypothesis $(\mathrm{EMH})$, which became a widely accepted investment theory throughout the latter part of the $20^{\text {th }}$ Century. The guiding principles of the EMH state that 1) stock price movements are independent of prior price movements, 2) all available information is reflected in a security's price and new information is quickly incorporated into the price, and 3) a firm's stock price is solely dependent on its risk-return relationship.

The EMH portrays both technical and fundamental analysis as futile efforts to outsmart the market and instead advocates a random, passive buy-and-hold investment strategy that relies on the market to efficiently price securities. The current study tests the semi-strong form EMH through the analysis of a straddle position's profitability during a corporate lawsuit. News of the lawsuit and its verdict are public information, and therefore the semi-strong form EMH states that one should not be able to systematically earn a profit solely through trading on this information.

Behavioral finance emerged in the early 1980s as a response to a growing body of literature on persistent market patterns and anomalies that challenged the EMH. Behavioral finance is defined as the study of systematic and prolonged anomalies that do not reflect rational market behavior [Shleifer. 2000, p. 2]. The scholars who introduced behavioral finance theory refuse to believe the EMH captures all aspects of investors' behavior and its consequences. Fama offered a 1998 response to the growing body of research in support of behavioral finance, contending that market overreaction is as likely to occur as under-reaction; he suggested that fallacious models have been used to find evidence of systematic abnormal returns and market "anomalies." Still, much research is dedicated to refuting the efficient markets theory.

De Bondt's and Thaler's [2005] Overreaction Hypothesis offers a behavioral finance theory in which investors tend to overreact to new information, leading to a sudden increase or decrease in stock price followed by a subsequent price reversal known as a market correction phenomenon. Through their Cumulative Average Returns (CARs) calculations, they find that stocks experiencing a sudden price decline outperform stocks with an initial price increase during the months following the initial price changes. Mun et al. [2000] corroborate these findings in their research into the Overreaction Hypothesis. They find that stocks' betas do not fully explain the differences among abnormal returns and thus conclude that market inefficiency and overreaction exist, as stocks are not rationally priced according to risk and return.

A significant amount of contemporary research specifically examines investor overreaction and abnormal returns in the event of lawsuits. Viscusi and Hersch [1990], Prince and Rubin [2002], and Bhagat, Bizjak, and Coles [1998] find evidence that lawsuit filing announcements result in abnormal stock price returns. Muoghalu, Robison, and Glascock [1990] corroborate these findings, but find no evidence of abnormal returns for verdict announcements. In the current study, abnormal returns may be evident if systematic mispricing occurs with respect to lawsuit firms' stock prices and/or option prices during the course of the lawsuit. 
The role of price volatility is central to the options market, and investors' expectations regarding volatility are difficult to model. The first widely used options pricing model comes out of Black and Scholes' research [1972] and has since become the standard for pricing options. Black and Scholes develop their equation for valuing options as a function of the price of the underlying asset and time. Essentially, the option's time to expiration is positively related to the level of uncertainty and possibility for price volatility, so options with longer periods to expiration tend to be priced higher.

The current study builds on prior research by integrating the theories of the Overreaction Hypothesis, abnormal returns in the event of a lawsuit, and expectations about volatility in tandem with options pricing. If abnormal risk-adjusted profits are evident, the semi-strong form EMH will not be supported, and the results will provide evidence in support of behavioral finance theories. In the event that positive abnormal returns do exist, new straddle options trading strategies may be devised based on the evidence.

\section{DATA AND METHODOLOGY}

The 31 lawsuits included in the study are obtained from Corporate Law Daily and The National Law Journal's "Largest Verdicts of 2002 and 2003." These publications provide the details for the announcement date and monetary damages awarded. Historical stock prices and betas for the lawsuit firms come from Yahoo! Finance. Stock prices are recorded for the announcement date, one month prior to the announcement date, three months prior to the announcement date, and five months prior to the announcement date. Historical option premiums and exercise prices for the 2002 and 2003 years are acquired through www.historicaloptiondata.com.

The current study hypothesizes that a firm's stock price is likely to drastically change immediately following the announcement of a verdict or settlement, hence a straddle options position taken several months prior to the announcement should yield a profit. Further investigation will be conducted to answer the questions of whether the lawsuit type, amount of monetary damages, or amount of time between buying the straddle and the announcement affects the straddle's profitability.

To determine whether the straddles outperformed the market during the corresponding time periods, straddle returns are compared to CAPM returns expected with a buy-and-hold strategy. The sample of lawsuits is then grouped by amount of monetary damages into small settlement and large settlement firms. The average of the small settlement group is $\$ 7,001,714.29$, while the average of the large settlement group is $\$ 2,775,912,362.35$. Alternatively, the lawsuits are also grouped into categories according to six lawsuit types that include Antitrust, Class Action, Discrimination, Government Non-Antitrust, Patent Infringement, and Product Liability. The straddle profits also have three categories based on the amount of time between purchasing the straddle and the announcement (1-month, 3-month and 5-month). Comparisons of returns are conducted for the respective categories and their portfolios with the aim of developing new straddle trading strategies.

\section{RESULTS AND ANALYSIS}

Once the straddle profits were calculated, it was shown that $155(46.69 \%)$ yielded a positive dollar profit, while $177(53.31 \%)$ were unprofitable. However, when the straddles were grouped by size of monetary damages, type of lawsuit, and time between the straddle purchase and the announcement date, several patterns became evident. $^{1}$

Of the 177 profitable straddles, $120(77.42 \%)$ come from large settlement firms and 35 (22.58\%) from small settlement firms. Although slightly less than half the straddles tested result in positive profits, a majority of the large settlement lawsuits achieve positive results. This finding may imply that investors do anticipate the consequences of a lawsuit to some degree, but are unable to prepare for large monetary damages. Therefore the risk

\footnotetext{
${ }^{1}$ Other tests were performed on the straddle calculations, but none were pertinent to the current study's trading
} strategies and implications. Please contact the authors for more information on the additional straddle analyses. 
of small damages may play a part in the options' premiums, but the risk of a large settlement is not reflected in the relevant securities' prices prior to the announcement.

When lawsuits are categorized by type of suit as opposed to size of settlement, several trends become apparent. Following is a list of the types of suits included in the sample and their relative straddle positive returns: Antitrust, with 10 of $12(83.33 \%)$ straddles having a positive return, Patent Infringement, where 34 of $56(60.71 \%)$ straddles are profitable, Product Liability, where 78 (59.1\%) of 132 straddles returns are positive, Government NonAntitrust, with 8 of $20(40 \%)$ profitable straddles, Discrimination, with 18 of $72(25 \%)$ straddles yielding a positive return, and lastly Class Action, where 7 of $40(17.5 \%)$ straddles in the sample are advantageous. Due to the differing sample sizes for each type of lawsuit, caution must be exercised when interpreting the results - antitrust, product liability, and patent infringement suits had a clear advantage over the other types of suits in terms of straddle profitability. One thing these types of suits all have in common is a change in the way a firm can sell or market a product, which is likely to influence investor confidence and firm revenues. The market may anticipate these serious consequences for these three types of lawsuits, which might explain why those suits are often more profitable.

Along with lawsuit type, the amount of time between purchasing the straddle and the announcement also appears to be a significant variable in straddle profits. Due to incomplete option data for 2002, only 24 of the 31 lawsuits are used in this comparison. Half the firms demonstrate the greatest return when the straddle is undertaken one month prior to the announcement, $4(16.67 \%)$ yield the greatest return with a straddle taken three months prior, and $8(33.33 \%)$ result in the highest return when the straddle position is adopted five months before the announcement. The fact that half the straddles' profits were maximized when purchased one month before the announcement suggests market inefficiency. In a highly publicized lawsuit, information regarding the case and its likely outcome are revealed periodically during the lawsuit, thus providing the investor with useful potential outcome information prior to the actual verdict announcement. As the trial nears its close, media coverage usually increases. Therefore, when the news indicates that the conclusion of the trial is near, it is the optimal time for investors to capitalize on information regarding potential outcomes. Armed with this plethora of information, the market should bid up the cost of the straddle accordingly, but this does not always appear to be the case.

One-third of the straddles' maximum profit occurred when the straddle was taken five months before the announcement, which is in accordance with the EMH. As investors have less access to information early in the trial regarding likely outcomes, they may find no reason to forecast future volatility and consequently may not bid up option prices. When option premiums are low, the likelihood of a profitable straddle increases because the underlying stock price need not vary much to cover the low straddle cost.

\section{TRADING IMPLICATIONS}

When the previously discussed differences among straddle returns are considered, new straddle trading strategies can be formulated to capitalize on price inefficiencies in the presence of specific types of lawsuits. The following three strategies are based on manipulation of the return data to identify the lawsuit criteria that result in a profitable straddle.

\section{One-Month, Patent Infringement, Large Settlement Straddles}

The most profitable straddles in the sample are those taken one month prior to the announcement in a patent infringement lawsuit. For the 6 patent infringement lawsuits firms, 24 possible straddles calculations are made to account for the possibility of exercising the options on day 1, 2, 3 or 4 . Of these 24 potential straddle scenarios, $22(91.67 \%)$ are profitable. When one straddle is purchased for each of the six firms in this category one month prior to the verdict announcement, the total return for the portfolio when the straddles are exercised on Day 1 is $57.33 \%$. This return takes into account the fact that one of the six straddles in the portfolio is a total loss (-100\%). If the criteria are refined further so that lawsuits must also have large settlements to be included, all $16(100 \%)$ of the straddles that meet the criteria are profitable. This return obviously exceeds the -.06\% CAPM 1-month expected 
return for a buy and hold position on the same portfolio of firms. When all of these straddles are bought one month prior to the announcement, the cumulative return on the straddles is $141.39 \%$.

A comparison of the 1-month, 3-month, and 5-month returns for this portfolio and the two yet to be outlined as well as the number of lawsuits in each portfolio can be seen in Table 1. The details for the firms included in the one-month, patent infringement, large settlement portfolio including individual returns (when the straddle is exercised on the day of the announcement) can be seen in Table 2. For a conservative investor who is looking for a relatively safe options trading scheme, investing in straddles consisting of a call and put with 6-month expiration dates approximately one month prior to the announcement of a (large) settlement or verdict in a patent infringement lawsuit appears to be a viable strategy.

Table 1

One-Month, Three-Month, And Five-Month Straddle Returns And Sample Sizes For The Three Lawsuit Portfolios

\begin{tabular}{|c|c|c|c|}
\hline Trading Strategy & $\begin{array}{l}\text { 1-Month, } \\
\text { Day } 1\end{array}$ & $\begin{array}{l}\text { 3-Month, } \\
\text { Day } 1\end{array}$ & $\begin{array}{c}\text { 5-Month, } \\
\text { Day } 1\end{array}$ \\
\hline Large Settlement, Patent Infringement & $141.39 \%$ & $54.59 \%$ & $-100.00 \%$ \\
\hline Number of Lawsuits in Portfolio & $\mathrm{n}=4$ & $\mathrm{n}=3$ & $\mathrm{n}=1$ \\
\hline Large Settlement, Product Liability & $53.94 \%$ & $43.77 \%$ & $58.70 \%$ \\
\hline Number of Lawsuits in Portfolio & $\mathrm{n}=10$ & $\mathrm{n}=10$ & $\mathrm{n}=10$ \\
\hline Large Settlement, Patent Infringement \& Product Liability & $70.30 \%$ & $45.49 \%$ & $43.41 \%$ \\
\hline Number of Lawsuits in Portfolio & $\mathrm{n}=14$ & $\mathrm{n}=13$ & $\mathrm{n}=11$ \\
\hline Large Settlement, Diversified Lawsuits & $36.74 \%$ & $30.63 \%$ & $22.31 \%$ \\
\hline Number of Lawsuits in Portfolio & $\mathrm{n}=16$ & $\mathrm{n}=16$ & $\mathrm{n}=14$ \\
\hline
\end{tabular}

\section{One-Month, Patent Infringement and Product Liability, Large Settlement Straddles}

The five most profitable lawsuits in the sample were all either patent infringement or product liability suits. All five were in the large settlement category and had maximum straddle returns ranging from $420.8 \%$ to $998.29 \%$. Even the minimum straddle returns for these suits were between $137.64 \%$ and $347.64 \%$. Four of these suits' maximum profits occurred when the straddle was taken one month prior to the verdict announcement. When all the CAPM expected returns for the patent infringement and product liability suits are averaged, the expected return on the portfolio is $-.03 \%$, which makes the $70.3 \%$ return on the 1-month straddle portfolio appear extremely attractive. However, not all large settlement, patent infringement/product liability suits were profitable. To illustrate the two individual components of this strategy, the large settlement, patent infringement and product liability portfolio returns are shown in Table 1 for 1-month, 3-month, and 5-month straddles. The table also presents the return of the overall portfolio that consists of both types of suits. The firms included in the one-month, patent infringement and product liability, large settlement portfolio and their individual settlements, profits, and returns appear in Table 3 on the following page.

For an investor who is not extremely risk-averse, straddles taken one month prior to a (large) settlement or verdict announcement in patent infringement or product liability cases is a strategy that has the potential for enormous abnormal returns.

Table 2

One-Month, Patent Infringement, Large Settlement Firms' Straddle Returns When Exercised On Day 1

\begin{tabular}{|c|c|c|c|}
\hline Lawsuit Firm & Monetary Damages & Profit in Dollars & Return as Percentage \\
\hline MSFT & $\$ 520,600,000.00$ & $\$ 0.34$ & $6.94 \%$ \\
\hline BJS & $\$ 98,100,000.00$ & $\$ 14.34$ & $699.51 \%$ \\
\hline HAL & $\$ 98,100,000.00$ & $\$ 8.81$ & $800.91 \%$ \\
\hline HIG & $\$ 118,340,000.00$ & $\$ 0.89$ & $43.41 \%$ \\
\hline
\end{tabular}




\section{One-Month, Diversified Lawsuits, Large Settlement Straddles}

A good options strategy for the investor who subscribes to the concept of a well-diversified portfolio entails buying into a variety of straddles related to lawsuits where the monetary damages are expected to be substantial, one month prior to the settlement or verdict announcement, regardless of the type of lawsuit. The empirical evidence for this strategy lies in the comprehensive return of one-month large settlement straddles. The 1-month, 3-month, and 5-month returns for the large settlement, diversified lawsuits portfolio can be found in Table 1. The individual lawsuits that make up this portfolio and their relevant calculations and characteristics can be seen in Table 4 .

The $36.74 \%$ total return of these 16 straddles greatly exceeds the one-month CAPM expected rate of return for any of the individual securities included in this sample, as well as the $-.07 \%$ (negative) average 1-month expected rate of return for the large settlement firm portfolio.

Table 3

One-Month, Patent Infringement \& Product Liability, Large Settlement Firms' Straddle Returns When Exercised On Day 1

\begin{tabular}{|c|c|c|c|}
\hline Lawsuit Firm & Monetary Damages & Profit in Dollars & Return as Percentage \\
\hline MSFT & $\$ 520,600,000.00$ & $\$ 0.34$ & $6.94 \%$ \\
\hline BJS & $\$ 98,100,000.00$ & $\$ 14.34$ & $699.51 \%$ \\
\hline HAL & $\$ 98,100,000.00$ & $\$ 8.81$ & $800.91 \%$ \\
\hline HI & $\$ 118,340,000.00$ & $\$ 0.89$ & $43.41 \%$ \\
\hline MO & $\$ 28,000,000,000.00$ & $\$ 10.32$ & $259.57 \%$ \\
\hline IP & $\$ 500,200,000.00$ & $\$ 16.23$ & $0.00 \%$ \\
\hline PHG & $\$ 383,300,160.00$ & $\$ 0.00$ & $0.00 \%$ \\
\hline EQT & $\$ 318,750,000.00$ & $\$ 0.00$ & $412.27 \%$ \\
\hline PRU & $\$ 270,050,000.00$ & $\$ 15.46$ & $93.50 \%$ \\
\hline X & $\$ 261,700,000.00$ & $\$ 1.87$ & $0.00 \%$ \\
\hline F & $\$ 250,000,000.00$ & $\$ 0.00$ & $0.00 \%$ \\
\hline GM & $\$ 225,000,000.00$ & $\$ 0.00$ & $998.29 \%$ \\
\hline
\end{tabular}

Table 4

One-Month, Diversified Lawsuits, Large Settlement Firms' Straddle Returns When Exercised On Day 1

\begin{tabular}{|c|c|c|c|}
\hline Lawsuit Firm & Monetary Damages & Profit in Dollars & Return as Percentage \\
\hline MO & $\$ 28,000,000,000.00$ & 10.32 & $149.57 \%$ \\
\hline XOM & $\$ 3,500,000,000.00$ & 0 & $0.00 \%$ \\
\hline HB & $\$ 520,770,000.00$ & 0 & $0.00 \%$ \\
\hline MSFT & $\$ 520,600,000.00$ & 0.34 & $255.59 \%$ \\
\hline DNA & $\$ 500,200,000.00$ & 16.23 & $0.00 \%$ \\
\hline IP & $\$ 383,300,160.00$ & 0 & $0.00 \%$ \\
\hline EQT & $\$ 318,750,000.00$ & 0 & $412.27 \%$ \\
\hline PRU & $\$ 270,050,000.00$ & 15.46 & $93.50 \%$ \\
\hline X & $\$ 261,700,000.00$ & 1.87 & $0.00 \%$ \\
\hline F & $\$ 250,000,000.00$ & 0 & $0.00 \%$ \\
\hline GPC & $\$ 225,000,000.00$ & 0 & $998.29 \%$ \\
\hline BJS & $\$ 140,000,000.00$ & 17.47 & $99.68 \%$ \\
\hline HAL & $\$ 122,000,000.00$ & 6.23 & $699.51 \%$ \\
\hline HIG & $\$ 98,100,000.00$ & 14.34 & $800.91 \%$ \\
\hline
\end{tabular}


If this return could be maintained by continually engaging in straddles that fit the aforementioned criteria, the one-month return would yield the investor a $440.92 \%$ annual return on the straddle investments.

Although investors may question whether it is feasible to obtain information telling them precisely when to expect a verdict, research indicates at least at times, it is possible to approximate the date of a verdict. The archives of The Economic Times, a publication that deals primarily with corporate lawsuits, reveals articles covering ongoing trials and phrases such as "a verdict is expected next month," and "a verdict is expected in March-April 2002" [The Economic Times, 2007]. One of the profitable straddles in the study was taken on a Philip Morris (MO) lawsuit. For a Philip Morris suit that took place in 1999, the New York Times predicted on September $9^{\text {th }}$ that the date of the verdict would be December $8^{\text {th }}$ ["Smoker's Widow Sues in France," 2007]. The actual verdict announcement occurred on December $13^{\text {th }}$, which supports the notion that the media is fairly reliable when it comes to accurately predicting verdict dates. As long as investors are up to date with media coverage of highly publicized lawsuits, they should be armed with plenty of information to help them properly time their one-month straddles. Even if the verdict is delayed, and the straddle is taken three or five months prior to the announcement, the difference in profitability is likely to be minimal according to the current study's findings.

\section{LIMITATIONS AND AREAS FOR FUTURE STUDY}

The current study's small sample of 31 lawsuits was due to cost constraints and restricted availability of detailed lawsuit information. Additional research should aim to analyze a sample that includes an equal number of the different types of lawsuits as well as a larger overall number of lawsuits. Specific statistics would also be helpful in profitability analyses regarding average settlement amounts for the various types of lawsuits or within specific industries.

Lawsuits are one type of event that may cause large stock price changes, but by no means are they the only such event. A few other types of events that may cause similar price fluctuations might include earnings surprises or mergers. Future research should analyze and compare straddle returns in the presence of verdict or settlement announcements, earnings announcements, and merger announcements. New possibilities for trading strategies may arise when the different types of events are contrasted.

The current study relied on present $\beta$ information for the lawsuit firms and their competitors for CAPM calculations. However, the lawsuit data pertained only to 2002 and 2003, so the current $\beta$ may not be representative of firm betas four and five years ago. Changes in past and present betas may have biased the expected return calculations, so a future study should rely on betas that correspond to the same period as the events being studied.

Because the option datasets used in the current study only included options with 6-month expiration dates, future studies should focus on straddles using options with 1,3, and 6-month expiration dates. Options with longer expiration dates tend to be priced higher, so straddles using options with shorter time to expiration may prove to be even more lucrative.

Due to time constraints, the current study relied on past data for analysis. An interesting experiment would be to reproduce the three straddle options trading strategies outlined in this study in a real market environment. Therefore, the hypothetical trading strategies could be tested for their practicality in actual markets. This experiment with actual trades would also take transaction costs into account, which are always a key component of real market trading strategies.

Many factors influence returns aside from unusual events such as lawsuits, including the macroeconomic environment and expectations and individual events that pertain to specific firms, such as the introduction of a new $\mathrm{CEO}$ or the acquisition of another firm. In future research, a regression may be helpful in determining which characteristics are significant in explaining the differences in straddle returns. Within the regression, factors could be added to the current study, such as economic indicators, time of year (to investigate the January effect, for example), and firm profits/revenues. 


\section{CONCLUSIONS}

The current study hypothesized that price fluctuations due to verdict or settlement announcements can create a uniquely profitable straddle options trading opportunity, as long as the straddle is purchased before the announcement takes place. This empirical study reveals that slightly less than half the calculated straddles were profitable. However, when the straddles are categorized by lawsuit type, settlement amount, and amount of time between straddle engagement and announcement date, several subsets of straddles appear to be lucrative. The three new trading strategies presented provide support for the Overreaction Hypothesis and behavioral finance in that systematic profits appear to be available to the investor who is willing to research and closely monitor lawsuits and their predicted outcomes. Nevertheless, the current strategies were based on one sample of lawsuits and had the advantage of hindsight. The results of the current study may be sample specific. Further research should build on the current study's findings to either validate or refine the trading strategies gleaned from this study's results. If future research corroborates the current study's findings, behavioral finance theories and the Overreaction Hypothesis will be supported and new straddle trading strategies may prove to offer viable profit opportunities in the marketplace.

\section{REFERENCES}

1. Bhagat, Sanjai, John Bizjak, and Jeffrey L. Coles. The Shareholder Wealth Implications of Corporate Lawsuits. Financial Management 27, no. 4 (1998): 5-27.

2. Black, Fischer and Myron Scholes. The Valuation of Option Contracts and a Test of Market Efficiency. Journal of Finance 27, no. 2 (1972): 399.

3. Chicago Board Options Exchange. http://www.cboe.com/aboutcboe/History. Accessed Oct. 18, 2006.

4. De Bondt, Werner F. M. and Richard Thaler. Does the Stock Market Overreact? The Psychology of World Equity Markets. Volume 1 (2005): 113-25.

5. The Economic Times. http://economictimes.com. Accessed March 2, 2007.

6. $\quad$ EEOC Litigation Statistics. http://www.eeoc.gov/stats/litigation.html. Accessed Oct. 24, 2006.

7. Fama, Eugene F. Market efficiency, long-term returns, and behavioral finance. Journal of Financial Economics 49, no. 3 (1998): 283-306.

8. Fama, Eugene F. Random Walks in Stock Market Prices. Financial Analysts Journal September/October (1965): 55-59.

9. Koku, Paul Sergius, Anique A. Qureshi, and Aigbe Akhigbe. The Effects of News on Initial Corporate Lawsuits. Journal of Business Research 53, no. 1 (2001): 49-55.

10. Mun, Johnathan C., Geraldo M. Vasconcellos, and Richard Kish. The Contrarian/Overreaction Hypothesis: An Analysis of the US and Canadian Stock Markets. Global Finance Journal 11, no. 1-2 (2000): 53-72.

11. Muoghalu, Michael I., H. David Robison, and John L. Glascock. Hazardous Lawsuits, Stockholder Returns, and Deterrence. Southern Economic Journal 57, no. 2 (1990): 357-70.

12. The National Law Journal's Largest Verdicts of 2002. http://www.verdictsearch.com. Accessed October 5, 2006.

13. The National Law Journal's Largest Verdicts of 2003. http://www.verdictsearch.com. Accessed October 5, 2006.

14. The Options Industry Council. http://www.optionscentral.com/resources/brochures.jsp, Accessed Oct. 24, 2006.

15. Prince, David W. and Paul H. Rubin. The Effects of Product Liability Litigation on the Value of Firms. American Law and Economics Review 4, no. 1 (2002): 44-87.

16. Shleifer, Andrei. Inefficient Markets: An Introduction to Behavioral Finance. New York: Oxford University Press, 2000.

17. Smoker's Widow Sues in France. The New York Times. http://nytimes.com, Accessed March 2, 2007.

18. Viscusi, W. Kip and Joni Hersch. The Market Response to Product Safety Litigation. Journal of Regulatory Economics 2, no. 3 (1990): 215-30. 